\title{
PENGARUH EARNING POWER DAN FIRM SIZE TERHADAP EARNING MANAGEMENT PADA PT. ELNUSA, TBK PERIODE 2008-2017
}

\author{
Gina Sakinah \\ Akuntansi Syariah, UIN Sunan Gunung Djati Bandung \\ ginasakinah1004@gmail.com \\ Taufiq Ridwan Murtadho \\ STIE Tridharma \\ taufiqridwan10@gmail.com
}

\begin{abstract}
Financial statements become the main source of information for all parties because it provides an overview of the state of the company's performance for a certain period. Company profit information will provide an overview of the company's ability to manage the company effectively and efficiently. Earning management is an action taken by the manager in the presentation of financial statements. Earning power the company's ability to generate profit in each period. Firm size is a scale that classifies the size of a company by assessing the total level of assets, stock market value, log size, and others. This research uses descriptive methods and quantitative approaches using secondary data supported by literature and documentation studies. The results showed partial earning power has a significant influence on earnings management. But firm size has no significant effect on earnings management. Simultaneously, both free variables can contribute and can significantly affect earnings management with a contribution of $58.5 \%$.
\end{abstract}

Keywords: Earning Power, Firm Size, Earnings Management 


\begin{abstract}
ABSTRAK
Laporan keuangan menjadi sumber informasi utama untuk seluruh pihak karena memberikan gambaran keadaan kinerja perusahaan para periode tertentu. Informasi laba perusahaan akan memberikan gambaran kemampuan perusahaan dalam pengelolaan perusahaan secara efektif dan efisien. Earning management merupakan tindakan yang dilakukan oleh manajer dalam penyajian laporan keuangan. Earning power kemampuan perusahaan dalam menghasilkan laba disetiap periodenya. Firm size ialah skala yang mengklasifikasikan besar kecilnya perusahaan dengan menilai dari tingkat total aktiva, nilai pasar saham, log size dan lain-lain. Penelitian ini menggunakan metode deskriptif dan pendekatan kuantitatif menggunakan data sekunder didukung dengan studi kepustakaan dan dokumentasi. Hasil penelitian menunjukkan secara parsial earning power memberikan pengaruh signifikan terhadap earnings management. Namun firm size berpengaruh tidak signifikan terhadap earnings management. Secara simultan, kedua variabel bebas dapat berkontribusi dan mampu mempengaruhi secara signifikan terhadap earnings management dengan kontribusi sebesar $58,5 \%$.
\end{abstract}

Kata Kunci: Earning Power, Firm Size, Earnings Management 


\section{PENDAHULUAN}

Persaingan dunia bisnis semakin ketat membuat setiap perusahaan semakin kompetitif dan menonjol di dunia bisnis. Dalam proses persaingan dunia bisnis ini, perusahaan perlu mengatur seluruh aktivitas operasional dengan efektif dan efisien. Dengan begitu perusahaan akan menghasilkan kinerja yang baik. Jika perusahaan termasuk dalam dalam kategori baik akan berdampak pada seluruh stakeholder salah satunya akan meningkatkan tingkat kepercayaan investor kepada emiten.

Salah satu alat ukur yang digunakan untuk menilai kinerja perusahaan yaitu dengan menilai tingkat laba yang dihasilkan. Nilai laba pada setipa periode meningkat mencerminkan bahwa perusahaan mampu secara maksimal mengelola sumber daya yang ada (Astari \& Suryanawa, 2017). Laporan keuangan merupakan kunci informasi untuk berbagai pihak, baik itu pihak manajemen maupun pihak luar. Oleh karena itu laporan keuangan yang disajikan harus memuat informasi yang realistis sesuai dengan lingkungan bisnis perusahaan yang sebenarnya. Karena informasi inilah menjadi dasar pengambilan keputusan (Leng, 2002).

Berita yang terkandung dalam laporan keuangan yang paling di soroti yaitu informasi laba perusahaan. Kecenderungan dari pihak eksternal salah satunya investor menginginkan informasi laba yang dicapai perusahaan tinggi, karena investor berharap jika laba perusahaan tinggi kemungkinan dividen yang dibagikan juga akan tinggi. Adanya fenomena ini mendorong pihak manajemen untuk melakukan earnings management (Anggraeni \& Hadiprajitno, 2013).

Earnings management berbagai upaya yang dilakukan oleh manajemen perusahaan dalam pelaporan laba. Earnings management terjadi karena berbagai prasyarat, salah satunya pengaruh terhadap pasar saham, peningkatan remunerasi manajeemn, mengurangi kemungkinan pelanggaran perjanjian kredit dan menghindari campur tangan pemerintah. Earnings management digunakan untuk meningkatkan kepercayaan para pemegang saham terhadap persahaan (Oktavia, 2012).

Earnings management dilakukan karena dilatarbelakangi adanya konflik yang terjadi antara principal dan agent. Dari pihak prinsipal memiliki kepentingan untuk memperoleh profitabilitas sebanyak mungkin sehingga dapat mencapai tingkat pengembalian saham yang maksimal. Sedangkan agent memiliki kepentingan untuk memperoleh komponsasi yang maksimal agar tercapai kemakmurannya. Maka hal ini menjadi alasan mengapa agent melakukan managemen laba. Earnings management menggambarkan adanya ketidakefektifian proses pengawasan sehingga pihak agent dapat melakukan hal ini (Anugerah \& Kurnia, 2014). 
Earnings management yang dilakukan oleh manajer dipicu karena berbagai faktor, diharapkan akan memberikan manfaat yang baik demi keberlangsungan hidup perusahaan. Tindakan ini tidak selalu bersifat negatif, tidak selalu diartikan sebagai proses manipulasi data melainkan sebagai pemilihan metode akuntansi untuk mengatur keuntungan yang diperbolehkan sesuai dengan accountings regulations (Gumanti, 2000).

Beberapa faktor yang dapat mempengaruhi earnings management salah satunya yaitu earning power dan firm size. Earning power kemampuan manajemen dalam menghasilkan laba disetiap periodenya. Investor berasumsi jika perusahaan memiliki earning power yang tinggi pengembalian investasi akan terjamin (Riyanto, 2008). Dengan melakukan analisis terhadap earning power investor dapat menilai kemampuan emiten memperoleh keuntungan dan tingkat efisiensi manajemen perusahaan di masa lalu.

Earning power ialah kemampuan untuk mengetahui efisiensi perusasahaan dalam melihat besar kecilnya dalam menghasilkan laba. Karena jika earning power tinggi maka kemungkinan dalam pengembalian investasi akan tinggi, hal inilah yang diinginkan oleh investor. Maka dari itu perushahaan harus dapat memaksimalkan manajemennya agar memiliki earning power yang maksimal (Sarjito et al., 2016).
Terdapat bukti empiris yang menyatakan bahwa earning power berpengaruh signifikan terhadap earnings management seperti hasil penelitian yang dilakukan oleh Melda dkk (2020) dan juga hasil penelitian yang dilakukan oleh Taco \& Ilat (2016) juga menyatakan bahwa earning power memiliki pengaruh signifikan terhadap earnings managenet.

Namun juga terdapat bukti empiris yang menyatakan bahwa earning power memiliki pengaruh tidak signifikan terhadap earnings management seperti hasil penelitian yang dilakukan oleh Alhavid (2015) dan penelitian yang dilakukan oleh Rosady \& Abidin bahwa earning power tidak berpengaruh signifikan terhadap arning management (2019).

Faktor lain yang dapat mempengaruhi earnings management ialah firm size. Firm size skala yang menghitung ukuran suatu perusahaan dengan menilai tingkat total asset, nilai pasar saham, ukuran majalah, dan faktor-faktor lainnya (Dewantari et al., 2020). Firm size menentukan tingkat kepercayai investor kepada emiten. Jika perusahaan berskala besar tentunya akan banyak dikenal oleh masyarakat. Dengan demikian informasi yang diperoleh akan meningkatkan nilai perusahaan. Selain itu perusahaan dengan tingkat total aset yang tinggi akan menarik minat investor untuk berinvestasi (Novari \& Lestari, 2016).

Firm size dapat menjadi patokan besar kecilnya satu perusahaan yang dilihat dari segi besarnya aktiva perusahaan 
pada akhir peridoe. Perusahaan yang berskala besar cenderung sering melakukan management laba karena perusahaan besar memiliki biaya lebih besar sehingga berporensi melakukan earnings management (Rosady \& Abidin, 2019).

Bukti empiris yang menyatakan bahwa firm size memiliki pengaruh signifikan terhadap earnings management seperti penelitian yang dilakukan oleh Purnama \& Taufiq bahawa firm size memiliki pengaruh signifikan terhadap earnings management. Selras dengan penelitian yang dilakukan oleh Rice (2013) bahwa besar nya nilai firm size dapat menjadi penentu earnings management.

Namun terdapat juga bukti empriris yang berbeda bahwa firm size tidak mampu mempengaruhi dengan signifikan terhadap earnings management seperti penelitian yang dilakukan oleh Sosiawan (2012). Dan hasil penelitian yang dilakukan oleh Insani (2017) bahwa firm size tidak mampu mempengaruhi dengan signifikan terhadap earnings management.

Pada penelitian kali ini, penulis akan menguji pengaruh variabel independen terhadap variavel dependen pada PT. Elnusa, Tbk peridoe 2008-2017. Perusahaan yang bergerak di bidang jasa upstream minyak gas dan bumi terkemuka. Laporan keuangan yang menjadi sumber data sekunder di unduh dari halaman website resmi perusahaan yaitu www.elnusa.co.id.

\section{Kajian Pustaka}

Earning Power

Pada dasarnya tujuan perusahaan ialah menghasilkan laba. Perusahaan melakukan analisis pada profitabilitas perusahaan untuk melihat sejauh mana kemampuannya dalam menghasilkan laba serta mengevalusi efektifitas perusahaan dari tahun sebelumnya. Karena rasio ini mengukur sejauh mana perusahaan menghasilkan keuntungan operasional dapat diperoleh dari setiap rupiah penjualan (Sosiawan, 2012).

Earnings power merupakan gambaran kemampuan perusahaan dalam menghasilkan laba perusahaan. Semakin meningkatnya earnings power semakin besar dorongan manajemen untuk melakjukan earnings management. Terlebih perusahaan manufaktur cenderung sering mengalami ketidak stabilan karena terdapat berbagai faktor yang menjadi penyebabnya (Taco \& Ilat, 2016).

\section{Firm Size}

Menurut Riyanto Firm Size merupakan menggambarkan besar kecilnya suatu perusahaan yang ditunjukkan pada total aktiva, jumlah penjualan, rata-rata penjualan dan total aktiva (Riyanto, 2008). Sedangkan menurut Brighman dan Houston Firm Size merupakan rata-rata total penjualan bersih untuk tahun yang bersangkutan sampai beberapa tahun. Dalam hal ini penjualan lebih besar dari pada biaya variabel dan biaya tetap, maka akan diperoleh jumlah pendapatan 
sebelum pajak. Sebaliknya jika penjualan lebih kecil dari pada biaya variabel dan biaya tetap maka perusahaan akan mengalami kerugian (Brigham \& Houston, 2007).

Perusahaan yang termasuk dalam kategori besar yaitu perusahaan yang tumbuh sehingga mempengaruhi jumlah profitabilitas perusahaan, karena jika profit meningkat akan menarik investor yang kemudian akan meningkatkan permintaan saham, maka harga saham akan menjadi tinggi dengan begitu akan berimbas pada tingginya nilai perusahaan, maka besar kecilnya ukuran perusahaan secara langsung berpengaruh terhadap nilai-nilai dari perusahaan tersebut (Angga \& Wiksuana, 2018).

\section{Earning Management}

Earnngs management merupakan upaya memanipulasi laporan keuangan yang bertujuan untuk menciptakan kinerja perusahaan menjadi lebih baik lagi. Dilakukan oleh pihak manajemen ketiga adanya pelaporan keuangan perusahaan dengan harapan mendapatkan suatu manfaat atas apa yang dilakukan. (Sherry et al., 2020). Ada beberapa penyebab terjadinya upaya untuk melakukan earnings management diantaranya ialah oleh teori keagenan setiap individu akan memiliki kepentingan untuk dirinya sendiri maka hal ini menjadi konflik kepentingan dalam perusahaan (Alhavid, 2015).

Rekayanya dalam laporan keuangan dapat menyebabkan distoris akuntansi yang mana manajer dapat memilih bagian mana yang akan di manipulasi atau untuk mempercantik laporan keuangan (wondow-dressing). Sebenarnya earnings management merupakan hasil akuntansi akrual yang paling bermasalah. Karena akuntansi akrual mengisinkan perusahaan untuk memilih metode yang sesuai dengan keadaan perusahaan. Dengan begitu dengan adanya kebebasa ini manajer dapat dengan bebas merubah angka-angka dalam akuntansi (Rice, 2013)

\section{Metodologi}

Pada penelitan ini menggunakan metode deskriptif melalui pendekatan kuantitatif dengan menggunakan bentuk data numerik, dan hubungan antarvariabel melalui analisis menggunakan alat uji statistik. Data yang dipakai diambil dari laporan keuangan keempat perusahaan yang menajdi objek dalam penelitian ini di unduh dari website resmi perusahaan yaitu www.elnusa.co.id. Metode menganalissi data secara statistik dan kuantitatif didukung dengan alat bantu software SPSS, perhitungan yang dipakai ialah analisis sebab akibat, signifikansi, dan keeratan hubungan. 
Tabel 1 Operasionalisasi Variabel

\begin{tabular}{|c|c|c|c|c|}
\hline Variabel & Definisi & Indikator & Rumus & Skala \\
\hline $\begin{array}{l}\text { Earning } \\
\text { Power }\end{array}$ & 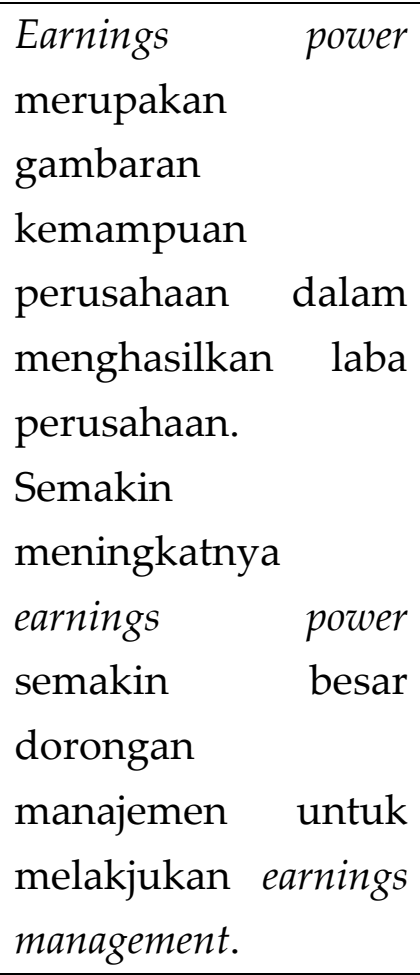 & $\begin{array}{c}\text { Keuntunga } \\
\text { n Bersih } \\
\text { Pendapatan } \\
\text { Bersih }\end{array}$ & $=\frac{\text { Keuntungan Bersih }}{\text { Pendapatan Bersih }} \times 100 \%$ & Rasio \\
\hline Firm Size & $\begin{array}{l}\text { Firm Size merupakan } \\
\text { menggambarkan } \\
\text { besar kecilnya suatu } \\
\text { perusahaan yang } \\
\text { ditunjukkan pada } \\
\text { total aktiva, jumlah } \\
\text { penjualan, rata-rata } \\
\text { penjualan dan total } \\
\text { aktiva }\end{array}$ & Total Asset & Ln $\times$ Total Asset & Rasio \\
\hline $\begin{array}{l}\text { Earnings } \\
\text { Manageme } \\
\text { nt }\end{array}$ & $\begin{array}{l}\text { Earnngs management } \\
\text { merupakan upaya } \\
\text { memanipulasi } \\
\text { laporan keuangan } \\
\text { yang bertujuan } \\
\text { untuk menciptakan } \\
\text { kinerja perusahaan } \\
\text { menjadi lebih baik } \\
\text { lagi. }\end{array}$ & $\begin{array}{c}\text { Total } \\
\text { Accrual } \\
\text { Non } \\
\text { discretionary } \\
\text { accrual }\end{array}$ & $\begin{array}{l}\text { Total Accrual - Non } \\
\text { discretionary accrual }\end{array}$ & Rasio \\
\hline
\end{tabular}


HASIL DAN PEMBAHASAN

Uji Normalitas

Perhitungan dalam pengujian ini menggunakan uji One-sample Kolmo- grov Smirnov. Berikut ini adalah efek samping dari komputasi menggunakan SPSS.

Tabel 1 Hasil Uji Normalitas

One-Sample Kolmogorov-Smirnov Test

\begin{tabular}{|c|c|c|}
\hline & & $\begin{array}{l}\text { Unstandardize } \\
\text { d Residual }\end{array}$ \\
\hline \multirow[t]{2}{*}{$\mathrm{N}$} & & 10 \\
\hline & Mean & 0E-7 \\
\hline \multirow[t]{2}{*}{ Normal Parameters ${ }^{\mathrm{a}, \mathrm{b}}$} & Std. & 127002605 \\
\hline & Deviation & 1.27072080 \\
\hline \multirow{3}{*}{$\begin{array}{c}\text { Most } \\
\text { Differences }\end{array}$} & Absolute & .232 \\
\hline & Positive & .232 \\
\hline & Negative & -.119 \\
\hline Kolmogorov-Smirnov Z & & .732 \\
\hline Asymp. Sig. (2-tailed) & & .657 \\
\hline
\end{tabular}

a. Test distribution is Normal.

b. Calculated from data.

Mengacu pada tabel yang telah instrumen eksplorasi memiliki sirkulasi disajikan, diperoleh hasil uji normalitas khas, karena 0,030<0,05. sebesar 0,675. Dengan demikian, dapat disimpulkan penelitian konsisten dengan asumsi normalitas, dimana semua

\section{Uji Multikolinearitas}

Dasar pengambilan keputusan pada uji ini diambil dengan nilai kewajaran $>$ 0,1 dan nilai VIF $<10$ 
Tabel 2 Uji Multikolinearitas

Coefficients $^{a}$

\begin{tabular}{|c|c|c|c|}
\hline \multirow{2}{*}{\multicolumn{2}{|c|}{ Model }} & \multicolumn{2}{|c|}{$\begin{array}{l}\text { Collinearity } \\
\text { Statistics }\end{array}$} \\
\hline & & $\begin{array}{l}\text { Toler } \\
\text { ance }\end{array}$ & $\mathrm{F}^{\mathrm{VI}}$ \\
\hline & (Constant) & & \\
\hline 1 & Earning Power & 1.000 & $\begin{array}{r}1.0 \\
00\end{array}$ \\
\hline & Firm Size & 1.000 & 1.0 \\
\hline
\end{tabular}

Mengacu pada tabel tersebut, independen, dan penelitian dapat diperoleh hasil earnings power dan firm size dilanjutkan.

untuk tolerance $1.000>0,01$ dengan nilai

VIF sebesar $1.000<10$. Dengan demikian disimpulkan bahwa multikolinearitas tidak muncul dalam model regresi ini, tidak ada hubugan antar variabel

\section{Uji Heterokedastisitas}

Uji heterokedastisitas diguakan untuk menunjukkan tidak adanya kesamaan varian. Menggunakan diagram pancar untuk melihat apakah penelitian ini heterokedastisitas.

Scatterplot

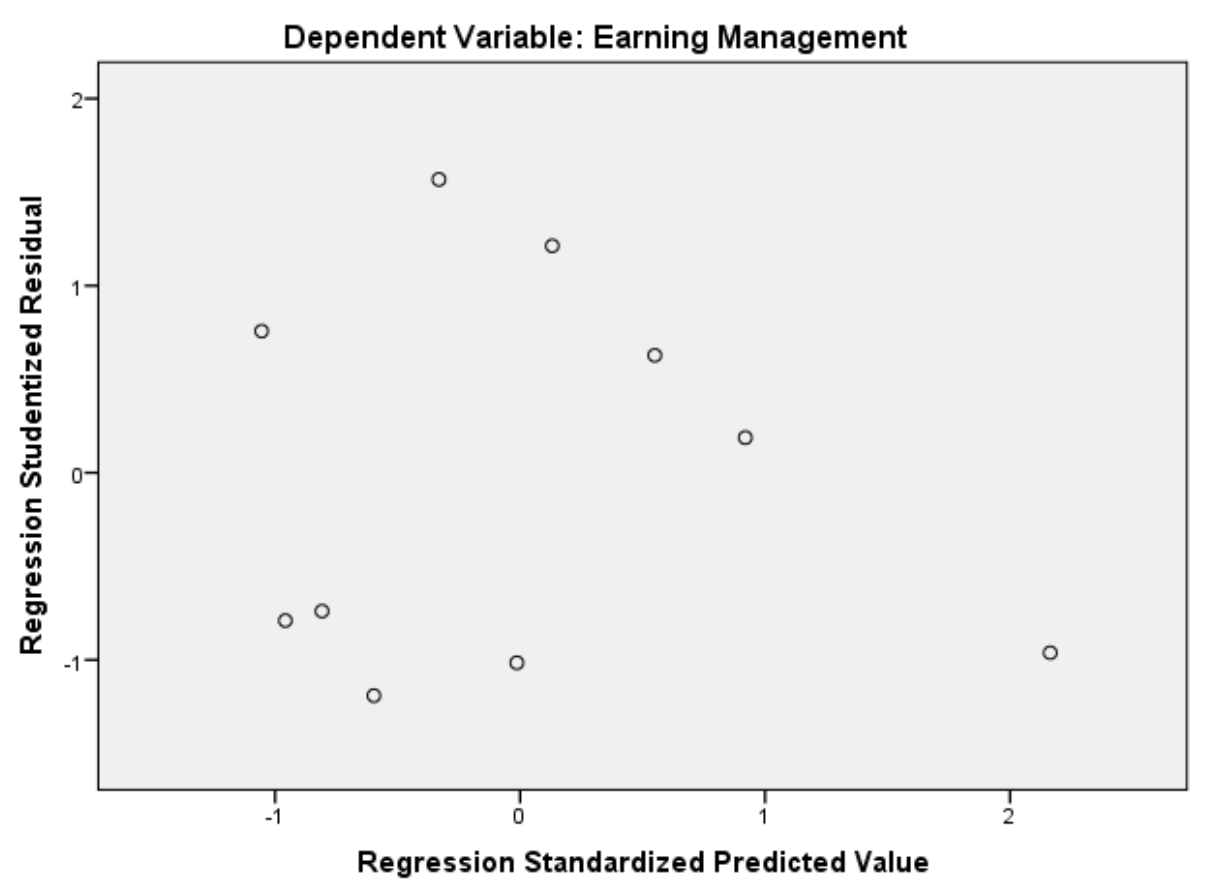




\section{Gambar 1 Hasil Uji Heterokedastisitas}

Sumber: Output SPSS versi 22.0

Berdasarkan diagram di atas, dapat diduga bahwa informasi dalam pemeriksaan ini terhindar dari heterokedastisitas mengingat informasi tersebut tersebar secara seampangan.

\section{Pengaruh Earning Power terhadap} Earnings Management pada PT. Elnusa, Tbk periode 2008-2017

Earning power menggambarkan kondisi keuangan suatu perusahaan yang menjadi landasan manajer dalam pengambilan keputusan. Selain pihak internal yang membutuhkan informasi ini yaitu ada pihak lain salah satunya investir dan kreditur membutuhkan informasi earning power sebagai acuan dalam proses penentuan investasi bagi investor dan penentuan besarnya pinjaman bagi kreditur (Surya et al., 2016).

Earning power dapat mempengaruhi dalam praktik earnings management baik dengan metode income increasing accrual ataupun income desscreasing accrual. Hal ini tergantung pada motivasi setiap perusahaan. Namun pada kenyataannya perusahaan yang mempunyai earning power yang optimal selalu mencerminkan kinerja perusahaan baik, karena praktik earnings management tetap dilakukan oleh pihak internal perusahaan (Pratiwi, 2008).

Berikut hasil penelitian yang telah dilakukan :

Tabel 3 Hasil Regresi Linear dan Uji t Pengaruh Earnings Power terhadap Earnings Management pada PT. Elnusa, Tbk peridoe 2007-2018

Coefficients $^{a}$

\begin{tabular}{|c|c|c|c|c|c|}
\hline \multirow[b]{2}{*}{ Model } & \multicolumn{2}{|c|}{$\begin{array}{l}\text { Unstandardized } \\
\text { Coefficients }\end{array}$} & \multirow{2}{*}{$\begin{array}{r}\begin{array}{r}\text { Standardize } \\
\text { d Coefficients }\end{array} \\
\text { Beta }\end{array}$} & \multirow[b]{2}{*}{$\mathrm{t}$} & \multirow[b]{2}{*}{ Sig. } \\
\hline & B & Std. Error & & & \\
\hline (Constant) & $\begin{array}{r}- \\
7.452\end{array}$ & 2.296 & & -3.245 & .012 \\
\hline $\begin{array}{l}\text { Earning_Po } \\
\text { wer }\end{array}$ & $\begin{array}{r}.8 \\
00\end{array}$ & .327 & .654 & 2.448 & .040 \\
\hline
\end{tabular}

a. Dependent Variabel: Earnings Management 
Mengacu pada tabel diatas, diperoleh persamaan sebagai berikut:

Earnings Management $=-7,452+0,800$

\section{Earning Power}

Sesuai dengan model persamaan yang telah disajikan mengandung arti bahwa ketika nilai variabel independen (earning power) bernilai nol, maka nilai variabel depneden (earnings management) akan berubah menjadi -7,452. Apabila variabel independen berubah sebesar 1 (satu) maa akan mengubah pada besarnya variabel dependen menjadi 0,800. Persamaan ini memiliki arah positif antara earning power terhadap earnings management.

Hasil pengujian hipotesis dengan menggunakan t-statisti menunjukkan pengaruh signifikan karena $t$ hitung $>t$ tabel yaitu 2,448 > 2,306. Maka dari itu pengujian ini dapat ditarik kesimpulan bahwa earnings management dipengaruhi oleh earning power secara signifikan.

Hasil penelitian ini sejalan dengan penelitian yang dilakukan oleh Taco \& Ilat (2016) menyatakan bahwa earning power berpengaruh signifikan terhadap earnings managemen. Juga selaras dengan hasil penelitian Melda dkk (2020) menyatakan bahwa earning power berpengaruh signifikan terhadap earnings management.

Selanjutnya dilakukan pengujian kekuatan hubungan dan kontribusi earning power terhadap earnings management. dengan hasil sebagai berikut:

Tabel 4 Uji Korelasi dan Koefisien Determinasi Earning Power terhadap Earnings Management pada PT. Elnusa, Tbk periode 2008-2017

Model Summary

\begin{tabular}{|c|c|c|c|c|}
\hline Model & $\mathrm{R}$ & $\begin{array}{c}\mathrm{R} \\
\text { Square }\end{array}$ & $\begin{array}{c}\text { Adjusted } \mathrm{R} \\
\text { Square }\end{array}$ & $\begin{array}{c}\text { Std. Error of the } \\
\text { Estimate }\end{array}$ \\
\hline 1 & $.654^{\mathrm{a}}$ & .428 & .357 & 3.90653 \\
\hline
\end{tabular}

a. Predictors: (Constant), Earning Power

Sumber: output SPSS versi 22.0

Mengacu pada hasil pengujian diatas, menejelaskan besarnya hubungan earning power terhadap earnings management sebesar 0,654 termasuk dalam kategori sedang. Dan hasil $\mathrm{R}$ Square $\left(\mathrm{r}^{2}\right)$ sebesar 0,428 atau sama dengan 42,8\%. Memiliki arti bawah earnings management dipengaruhi oleh earning power sebesar $42,8 \%$ sisanya $57,2 \%$ dipengaruhi oleh faktor lain.

Hasil pengujian menunjukkan earning power memiliki pengaruh signifikan terhadap earnings management. Implikasinya ialah perusahaan perlu melakukan analisis earning power dengan tepat, karena kekuatan pendapatan memiliki dampak positif. Menurut Statement of 
Financial Accounting Concepts (SFAC) No. 1 , informasi pendapatan menjadi perhatian utama karena dapat mencerminkan kinerja suatu perusahaan, selain itu informasi pendapatan dapat memberikan gambaran di masa yang akan datang mengenai seberapa besar earning power yang dicapai. Komponen dalam laporan keuangan yang menarik perhatian banyak pihak ialah laba bersih perusahaan, maka laba bersih paling mungkin dimanipulasi oleh manajer.

Walaupun laporan keuangan yang disajikan sesuai dengan keadaan selama periode tersebut, namun nilai profitabilitas tahun sebelumnya sangat berarti untuk tahun yang akan dating. Karena nilai profitabilitas akan di proyeksikan untuk masa yang akan datang. Akan mendapatkan pembiayaan yang besar dari investor maka perusahaan harus memiliki trend profitabilitas agar investor tertarik. Trend profitabilitas pada tahun $\mathrm{t}$ yang baik akan menunjukkan proyeksi profitabilitas tahun mendatang yang akan lebih baik dari tahun sebelumnya. Maka untuk menarik minat investor manajemen laba agar dapat membuktikan kepada investor bahwa laba tahun ini lebih baik dari laba tahun sebelumnya (Sosiawan, 2012).
Kemampuan perusahaan dalam menghasilkan yang baik tiap tahunnya merupakan cara untuk menarik investor. Mengukur kemampuan laba dnegan membandingkan laba bersih perusahaan dengan pendapatan yang dimiliki memang efektifitas dan dapat menggambarkan kemampuan pendapatan yang dikelola manajemen. Namun dalam penelitian ini pengaruhnya tidak terlalu besar. Secara keseluruhan hasil penelitian ini dapat membuktikan bahwa earnings power suatu perusahaan dapat mendorong manajer melalukan praktek manajemen laba (Insani, 2017).

\section{Pengaruh Firm Size terhadap Earnings} Management pada PT. Elnusa, Tbk

Firm size skala yang menggambarkan ukuran perusahaan yang diukur dnegan total penjualanm rata-rata penjualan dan total aset. Biasanya perusahaan besar akan memiliki total aset yang besar dan juga memiliki kemampuan untuk meningkatkan kepercayaan pemegang saham. Dampaknya jika banyak investor yang menanamkan modalnya akan mencapai pada harga yang tinggi (Habsari \& Akhmadi, 2018). Berikut hasil pengujian yang telah dilakukan : 
Tabel 5 Hasil Regresi Linear dan Uji t Pengaruh Firm Size terhadap Earnings Management pada PT. Elnusa, Tbk peridoe 2007-2018

Coefficients $^{a}$

\begin{tabular}{|c|r|r|r|r|r|}
\hline \multirow{2}{*}{ Model } & \multicolumn{2}{|c|}{$\begin{array}{l}\text { Unstandardized } \\
\text { Coefficients }\end{array}$} & $\begin{array}{r}\text { Standardiz } \\
\text { ed Coefficients }\end{array}$ & \\
\cline { 2 - 4 } & $\mathrm{B}$ & \multicolumn{1}{c|}{$\begin{array}{c}\text { Std. } \\
\text { Error }\end{array}$} & Beta & $\mathrm{t}$ & Sig. \\
\hline (Constant) & 284.703 & 212.533 & & 1.340 & .217 \\
Firm_Size & -18.788 & 13.893 & -.431 & - & .213 \\
\hline
\end{tabular}

a. Dependet Variabel: Earnings Management

Sumber: output SPSS versu 22.0

Merujuk pada tabel diatas, memiliki arah negatif antara firm size didapatkan model persamaan sebagai terhadapearnings management. berikut:

Earnings Management $=284,703-$ 18,788 Firm Size

Sesuai dengan model persamaan yang telah disajikan mengandung arti bahwa ketika nilai variabel independen (firm size) bernilai nol, maka nilai variabel depneden (earnings management) akan berubah menjadi 284,703. Apabila variabel independen berubah sebesar 1 (satu) maka akan mengubah pada besarnya variabel depen-

Hasil pengujian hipotesis dengan menggunakan $t$-statistic menunjukkan pengaruh tidak signifikan karena $t$ hitung $<t$ tabel yaitu $-1,532<2,306$. Maka dari itu pengujian ini dapat ditarik kesimpulan bahwa earnings management dipengaruhi oleh firm size secara tidak signifikan. Selanjutnya dilakukan pengujian kekuatan hubungan dan kontribusi firm size terhadap earnings management dengan hasil sebagai berikut: den menjadi $-18,788$. Persamaan ini

Tabel 6 Uji Korelasi dan Koefisien Determinasi Firm Size terhadap Earnings Management pada PT. Elnusa, Tbk periode 2008-2017

Model Summary

\begin{tabular}{|c|c|c|c|c|}
\hline Model & $\mathrm{R}$ & $\begin{array}{c}\mathrm{R} \\
\text { Square }\end{array}$ & $\begin{array}{c}\text { Adjusted } \mathrm{R} \\
\text { Square }\end{array}$ & $\begin{array}{c}\text { Std. Error of the } \\
\text { Estimate }\end{array}$ \\
\hline 1 & $.431^{\mathrm{a}}$ & .186 & .084 & 4.66093 \\
\hline
\end{tabular}

a. Predictors: (Constant), Firm Size

Sumber: output SPSS versi 22.0 
Mengacu pada hasil pengujian diatas menerangkan besarnya hubungan firm size terhadap earnings management sebesar 0,431 termasuk dalam kelompok rendah. Dan hasil R Square $\left(\mathrm{r}^{2}\right)$ sebesar 0,186 atau sama dengan 18,6\%. Memiliki arti bawah earnings management dipengaruhi oleh firm size sebesar $18,6 \%$ sisanya $81,4 \%$ dipengaruhi oleh faktor lain.

Hasil penelitian menunjukkan bahwa firm size tidak berpengaruh signifikan terjadap earnings management. hal ini terjadi karea adanya pengawasan yang kuat dari pemerintah, analis, dan investor menjadi penyebab manajer ragu melakukan tindakan tersebut. Karena jika perusahaan diketahui melakukan earning management akan merusak citra perusahaan dan kapabilitas pimpinan perusahaan. Sehingga manajer perushaan yang berikuran kecil maupun besar mengambil tindakan untuk tidak melakukan hal tersebut.

Hasil penelitian ini sejalan dengan bahwa firm size tidak mampu mempengaruhi dengan signifikan terhadap earnings management seperti penelitian yang dilakukan oleh Sosiawan (2012). Dan hasil penelitian yang dilakukan oleh Insani (2017) bahwa firm size tidak mampu mempengaruhi dengan signifikan terhadap earnings management.

Firm size tidak mampu mempengaruhi earnings management ialah karena motivasi dewan direksi untuk melakukan earnings management bukan berlandaskan karena ukuran perusahaan. Terjadi perbe- daan informasi antara dewan direksi dengan investor sehingga menjadi sebuah landasan dewan direksi untuk melakukan tindakan earnings management. Asimtetri informasi ini ditunjukkan dengan pemahaman dewan direksi terhadap kemampuan departementalisasi perusahaannya (Insani, 2017).

Perusahaan cenderung akan menghindari tuntutan dari pihak pemilik untuk memperoleh laba yang semakin besar di periode mendatang dan adanya kebijakan ekspansi di masa depan. Beberapa perusahaan yang mengalami kenaikan harga saham justru diikuti dengan meningkatnya laba. Dana seblaiknya ketika terjadi penurunan harga saham tidak selamanya diikuti dengan meningkatnya laba perusahaan. Hal ini menunjukkan bahwa dengan meningkatnya laba. Dan sebaliknya ketika terjadi penurunan harga saham tidak selamanya diikuti dengan peningkatan laba perusahaan (Rice, 2013).

\section{Pengaruh Earning Power dan Firm Size terhadap Earnings Management pada PT. Elnusa, Tbk periode 2008-2017}

Earnings management merupakan kebijakan akuntansi yang dilaksanakan oleh manajer berdasarkan standar akuntansi yang ada yang dapat memaksimalkan utilitas (Scott, 2012). Earnings management muncul akibat dari tindakan yang dilakukan oleh manajer dalam proses pelaporan keuangan yang diharapkan mendapatkan manfaat positif demi kepentingan perusahaan. 
Tabel 6 Uji Simultan Pengaruh Earning Power dan Firm Size terhadap Earnings Management pada PT. Elnusa, Tbk periode 2008-2017 ANOVA $^{a}$

\begin{tabular}{|c|c|c|c|c|c|}
\hline Model & Sum of Squares & $\mathrm{df}$ & $\begin{array}{l}\text { Mean } \\
\text { Square }\end{array}$ & $\mathrm{F}$ & Sig. \\
\hline $\begin{array}{l}1 \text { Regres } \\
\text { sion }\end{array}$ & 124.897 & 2 & 62.448 & $\begin{array}{l}4.93 \\
2^{2}\end{array}$ & $\begin{array}{l}.046 \\
\mathrm{~b}\end{array}$ \\
\hline ual ${ }^{\text {Resid }}$ & 88.629 & 7 & 12.661 & & \\
\hline Total & 213.526 & 9 & & & \\
\hline
\end{tabular}

a. Dependent Variabel: Earnings Management

b. Predictors: (Cosntant), Earning Power, Firm Size

Sumber: Output SPSS versi 22

Pada tabel di atas, terdapat tes dengan tingkat signfikansi 0,046. Untuk simultan dengan hasil earning power dan menguji kekuatan hubungan dan firm size berpengaruh signifkan terhadap kontribusi pengaruh earning power dan earnings management karena memenuhi firm size terhadap earnings management syarat yaitu $f$ hitung $>f$ tabel $4,932>4,737$ sebagai berikut:

Tabel 7 Hasil Uji Korelasi dan Determinasi Pengaruh Earning Power dan Firm Size terhadap Earnings Management pada PT. Elnusa, Tbk periode 2008-2017 Model Summary

\begin{tabular}{|c|c|c|c|c|}
\hline Model & $\mathrm{R}$ & $\begin{array}{c}\mathrm{R} \\
\text { Square }\end{array}$ & $\begin{array}{c}\text { Adjusted } \mathrm{R} \\
\text { Square }\end{array}$ & $\begin{array}{c}\text { Std. Error of the } \\
\text { Estimate }\end{array}$ \\
\hline 1 & $.765^{\mathrm{a}}$ & .585 & .466 & 3.55828 \\
\hline
\end{tabular}

a. Dependent Variabel: Earnings Management

b. Predictors: (Cosntant), Earning Power, Firm Size

Sumber: Output SPSS versi 22

Mengacu pada hasil pengujian diatas menerangkan besarnya hubungan earning power dan firm size terhadap earnings management sebesar 0,756 termasuk dalam kategori kuat. Dan hasil $\mathrm{R}$ Square $\left(\mathrm{r}^{2}\right)$ sebesar 0,585 atau sama dengan 58,5\%.
Memiliki arti bahwa earnings management dipengaruhi oleh earning power dan firm size sebesar $58,5 \%$ sisanya $41,5 \%$ dipengaruhi oleh faktor lain.

Earning management tidak selalu bersifat negatif. Menurut Watts dan 
Zimmerman memaparkan Positive Accounting Theory yaitu teori akuntansi positif memiliki peran yang sangat penting, mengandung pedoman mengenai keputusan akuntansi atas tindakantindakan yang dilakukan berikut menjelaskan konsekuensi yang akan ditanggung.

Alasan lain mengapa manajer melakukan earning management ialah untuk mengurangi biaya agensi (agency cost) dan juga biaya kontrak (contracting theory). Terdapat tiga sasaran dalam melakukan earning manageent yaitu minimasi biaya politis (political cost minimization), maksimisasi kesejahteraan maanjer (manager wealth maximization), maksimisasi (minimazation of financing cost). Tepatnya sasaran dilakukannya earning management ialah cukup komprehensif mencakup banyak aspek dalam perusahaan (Gumanti, 2000).

\section{SIMPULAN}

Akhir penelitian ini berisikan hasil akhir, earning power dapat mempengaruhi earning management secara parsial. Firm size tidak dapat mempengaruhi earning management secara parsial. Kedua variabel independen mampu mempengaruhi earning management dengan kontribusi sebesar 58,5\%. Implikasi pada penelitian ini ialah, earning management dapat dilakukan jika memang untuk kebaikan perusahaan dan pihak yang lain yang nantinya akan mendapatkan manfaat besar dari tindakan ini. Hal ini dilakukan karena berbagai faktor mulai dari upaya untuk tetap menjaga kepercayaan investor, meringankan biaya sewa serta manfaat yang lain. Selagi masih dalam ketentuan akuntansi. earning management dapat dilakukan. Proses earning management dipengaruhi oleh berbagai faktor, earning power dan firm Size menjadi menyumbang earning management. 


\section{DAFTAR PUSTAKA}

Alhavid. (2015). Pengaruh Earning Power dan Good Corporate Governance Terhadap Manajemen Laba. Jurnal Akuntansi, 3(1), 1-20.

Angga, P. I., \& Wiksuana, I. (2018). Pengaruh Firm Size dan Profitabilitas terhadap Nilai Perusahaan dengan Struktur Modal sebagai variabel mediasi. E-Jurnal Ekonomi Dan Bisnis Universitas Udayana, 7(5), 1289-1318.

Anggraeni, R. M., \& Hadiprajitno, P. B. (2013). Pengaruh Struktur Kepemilikan Manajerial, Ukuran Perusahaan, dan Praktik Corporate Governance terhadap Manajemen Laba. Diponegoro Journal Of Management, 2(3), 1-13.

Anugerah, R., \& Kurnia, P. (2014). Factors Affecting Earnings Management (Empirical Studies on Companies Listed on The Stock Exchange in The Period 2008-2011). JOM Fekon, 1(2), 1-14.

Astari, A. A. M. R., \& Suryanawa, I. K. (2017). Faktor-Faktor Yang Mempengaruhi Manajemen Laba. E-Jurnal Akuntansi, 20(1), 290-319.

Brigham, E. F., \& Houston, J. F. (2007). Essentials of Financial Management: Dasar-dasar Manajemen Keuangan Terjemah oleh Ali Akbar Yulianto. Salemba Empat.

Dewantari, N. L. S., Cipta, W., \& Susila, G. P. A. J. (2020). Pengaruh Ukuran Perusahaan Dan Leverage Serta Profitabilitas Terhadap Nilai Perusahaan Pada Perusahaan Food and Beverages Di Bei. Prospek: Jurnal Manajemen Dan Bisnis, 1(2), 74. https://doi.org/10.23887/pjmb.v1i2.23157

Gumanti, T. A. (2000). Earnings Management: Suatu Telaah Pustaka. Jurnal Akuntansi Dan Keuangan, 2(2), 104-115. https://doi.org/10.9744/jak.2.2.pp.104-115

Habsari, A., \& Akhmadi, A. (2018). Ukuran Perusahaan, Profitabilitas Dan Nilai Perusahaan: Studi Empirik: Perusahaan Sektor Pertambangan Yang Terdaftar Di Bursa Efek Indonesia Periode 2011 Sampai Dengan 2015). Tirtayasa Ekonomika, 13(2), 300-319. https://doi.org/10.35448/jte.v13i2.4316

Insani, K. (2017). Pengaruh Earnings Power dan Ukuran Perusahaan Terhadap Manajemen Laba. Jurnal Akuntansi, 5(2), 1-17.

Leng, P. (2002). Analisis Terhadap Perlunya Penyesuaian Laporan Keuangan Historis (Conventional Accounting) Menjadi Berdasarkan Tingkat Harga Umum (General Price Level Accounting). Jurnal Akuntansi Dan Keuangan, 4(2), 141-155. https://doi.org/10.9744/jak.4.2.pp.141-155 
Novari, P. M., \& Lestari, P. V. (2016). Pengaruh Ukuran Perusahaan, Leverage, Profitabilitas terhadap Nilai Perusahaan pada Sektor Properti dan Real Estate. EJurnal Manajemen Unud, 5(9), 5671-5694.

Oktavia. (2012). Dampak perubahan tariff pajak penghasilan badan terhadap perilaku manajemen. Jurnal Akuntansi, 12(1), 559-576.

Pratiwi, P. (2008). Pengaruh Earnings Power terhadap Manajemen Laba. Universitas Pendidikan Indonesia.

Rice. (2013). Pengaruh Leverage, Kepemilikan Institusional, Ukuran Perusahaan dan Nilai Perusahaan Terhadap Tindakan Manajemen Laba. Jurnal Wira Ekonomi Mikroskil, 3(1), 41-50.

Riyanto, B. (2008). Dasar-Dasar Pembelanjaan Perusahaan Edisi Keempat. BPFE.

Rosady, R. S. A., \& Abidin, K. (2019). Pengaruh Kompensasi Bonus Dan Leverage Terhadap Manajemen Laba (Studi Empiris Pada Perusahaan Manufaktur yang Terdaftar di Bursa Efek Indonesia Tahun 2009-2012). Liability, 2(2), 40-62.

Sarjito, S., Soetama, D. R., \& Ruliana, R. (2016). Pengaruh Earning Power Terhadap Earning Management. Jurnal Ilmu Akuntansi, 9(1).

Scott, W. R. (2012). Financial Accounting Theory. Person Education.

Sherry, M., Nadilla, T., Iskandar, Ramdhan, Ridha, A., \& Puspita, D. (2020). Pengaruh Earning Power dan Perubahan Tarif Pajak Terhadap Manajemen Laba Pada Perusahaan Perbankan yang telah Go Public di Bursa Efek Indonesia. Seminar Nasional Teknologi Komputer E Sains (SAINTEKS), 646-648.

Sosiawan, S. Y. (2012). Pengaruh Kompensasi, Leverage, Ukuran Perusahaan, Earning Power terhadap Manajemen Laba. JRAK, 8(1), 79-89.

Surya, S., Soetama, D. R., \& Ruliana, R. (2016). Pengaruh Earning Power Terhadap Earning Management. Akuntabilitas, 9(1), 97-120. https://doi.org/10.15408/akt.v9i1.3587

Taco, C., \& Ilat, V. (2016). Pengaruh Earning Power, Komisaris Independen, Dewan Direksi, Komite Audit dan Ukuran Perusahaan Terhadap manajemen Laba Pada Perusahaan Manufaktur Yang Terdaftar di Bursa Efek Indonesia. Jurnal Emba: Jurnal Riset Ekonomi, Manajemen, Bisnis Dan Akuntansi, 4(4), 873-884. 